\title{
Folklore as Tradition, Heritage and Profession
}

Rohan Kumar Soni

Assistant Professor (French)

Amity School of Languages

Amity University Chhattisgarh

Chhattisgarh, India

rohankrsoni@gmail.com

Folklore as a field of study and academic discipline was first recognized following the works of Johann Gottfried Herder in 1770s. The works of Herder, his collection of 'folktales' from German speaking regions is considered the base for later folklore collections, such as those done by the Brothers Grimm and Charles Perrault. Although the discipline of folklore is now well established in various institutions across the Americas, Europe and Africa and Asia. This paper tries to understand folklore in relation with the concepts such as Tradition, Heritage and Profession. How folklore in this fast changing world represents the heritage, tradition, and profession of a community? Can folklore and its performance be appreciated for its inherent economic potential as a profession? The paper, through certain examples and observation, will try to understand the significance of these concepts and attempt to answer such questions.

Keywords: Folklore, Tradition, Heritage, Profession, Garhwali Folk Songs, Folk. 
Defining folklore is a challenge to any folklorist or scholar as its definitions can be completely different from one another depending on the context and perspective. The folklore as a discipline has not received much attention in its own right although scholars from Sociology, History, Linguistics, Anthropology and other branches of Social Sciences and Humanities have given their precious attention to it and have attempted to define it from their perspective. As we proceed to understand folklore we must keep in mind its importance as perceived by society as well as by academics. There are some important basic characteristics that one can find largely in the definitions attempted by scholars. That being "knowledge belonging to people"; "a community's beliefs, customs and narratives which give them a sense of collective belonging"; "body of knowledge which has no particular author, community as a whole is its repository and every individual of that community can be its author.

When we talk about folklore both academically as well as in general, one is bound to evoke the 'Oral tradition' first. Although, folklore also includes the rituals, skills and craftsmanship that belongs historically to a particular community. We will strict our discussion only with its oral aspect.

The essence of folklore can be understood by what Alan Dundes, the great folklorist, very aptly described it as people's own description of themselves, an "autobiographical ethnography", as it permits a view from the inside-out rather than from the outside-in". (Bronner 55). Folklore as we understand it as 'Oral tradition', then can be described as an ensemble of knowledge, comprising folktales, fables, lores, fairy tales, legends, jokes, adage, tongue twisters, and the likes, which are passed on from generation to generation largely through word of mouth or apprenticeship. 
From lullabies and lores to Aesop's fables and Perrault's folktales, from Panchtantra and traditional marriage songs, to Epics and legends all these familiar oral narratives which we listen from our childhood throughout our lives are part of folklore. The individuals of a community identify themselves on the basis of these shared oral narratives. A community's true intangible asset lies in its' rich oral tradition.

Tradition is commonly seen as something old, which resists change or which is anti-reason. Commonly, people understand tradition as something their forefathers considered sacred, important or reasonable to follow for generations after generations and they are ought to carry it forward just because their forefathers did so. This is a very general understanding of tradition. In an enlightening essay, Yadgar tries to define tradition outlining three different analogies to shed light upon the complex nature of tradition. His analysis based upon the sociological reading of major philosophical works, argues :

“...this view would stress tradition's dynamic nature and the role of individual agent and of the relevant community in interpreting and maintaining tradition, arguing against conservative notions of tradition's alleged rigid 'eternal' and overtly authoritative nature - to the degree of almost celebrating tradition's supposed irrationality."(Yadgar 2013)

Tradition, therefore, is something very dynamic in nature. It belongs to present as much as it is part of the past. It is the individuals of the present who are the active contributor in maintaining the tradition. Tradition thus is not mere practice of following and carrying forward what your forefathers did, rather it is the transfer of practices which serve some practical purpose which can be as significant as uniting a family on an occasion to as insignificant as passing time in a unique manner. This passing on of knowledge and practices which serves 
some purpose, whether intended or unintended, can be termed as Tradition. Tradition also helps in keeping the community bonds intact and giving its members a sense of solidarity.

Heritage is the sum total of all the tangible and intangible assets and attributes which forms the legacy of a particular community or region. The term 'Heritage' refers to "that which has been or may be inherited, regardless of its value".(Sandis 2014) Heritage of a community is considered a source of aspiration and celebration for its people.

Heritage, per se, does not always refer to something positive or which can be celebrated, it may also evoke feelings of pity or disgrace. For example, one can never imagine to celebrate the heritage of Varna-system (caste stratification) in India or the heritage of slavery in the western world. The heritage, therefore, can evoke both positive and negative feelings but people and communities tend to overlook the negative aspects of it and celebrate what is approved by the community as their 'true' heritage. In this sense, therefore, the community, in the course of time, decides which part of its heritage needs censorship and what needs to be glorified for its celebration. Accordingly, the members of a community are encouraged to emphasise and glorify only the positive aspects of their heritage.

Profession is a specialised occupation which only people trained in that particular area can practice to earn their livelihood. Hughes defines it as "A profession delivers esoteric services-- advice or action or both-- to individuals, organizations or governments; to whole class or group of people or to the public at large".(Hughes 1963) A professional in a field is trained to offer services or perform certain actions either for an individual or for the public at large. Since to be a professional, one has to have a training in that field and it is only by formal education or through informal apprenticeship that one could achieve the proficiency required to be a professional. The passing on of the traditional economical roles as defined by caste system in India in which a son learns the skills and craftsmanship from his father, such as the 
services rendered by ironsmith, carpenter, potter or goldsmith can also be seen as a profession since they use their skills to render their designing services to individuals and communities at large.

To understand how the concept of folklore, tradition, heritage and profession can be understood in relation to one another, I would like to discuss the profession of folklore artists of Garhwal region of Uttarakhand India. In an inspiring participatory research done by Anjali Capila, titled Images of Women in the Folk Songs of Garhwal Himalayas, outlines The lives of the women of Garhwal region who do back-breaking work on the difficult hilly terrain, mostly, in the absence of their husbands because young male members leave their homes to go to the big cities and earn a livelihood for their families. These women while doing household chores on the field such as fetching drinking water and fodder for the cattle, collecting firewood etc. express their grief, pain, and aspirations through their songs.

This tradition of singing folk songs while performing household chores is an act so mesmerising that in recent times various NGOs have taken an initiative to recruit some of these women to perform folk songs on a full time basis and they are paid for their job. Their folklore is alive, imbibed in their culture and thriving because of their tradition of singing folk songs while working since generations. These folk songs are their intangible heritage and with the help of NGOs, the paid performance of these folk songs for the larger public has now become their profession.

"The Internet has become an essential tool of everyday life; it is also distinguished by being envisioned as a separate location or space in which traditions arise and are constituted" (Bronner 22). 
Internet can become a saviour for communities where the new generations are getting into 'modern' professions and are not giving due attention and appreciation to their traditional knowledge and folklore. This separate space can definitely be a repository for this plethora of knowledge we called folklore both in written as well as visual forms of it.

In this globalised IT dominated world, folklore is changing its form. Folklore is no more only oral, rather it is being talked about in books, blogs and videos and being consumed by the public through various media. This has also given scope for storytellers or folk artists to exercise their profession by 'performing' their folklore on various platforms which internet offers, by presenting their traditional knowledge and by celebrating their cultural heritage with the larger public. India is home to more than a dozen of such intangible cultural heritage. The folklore of various communities across the world is now infused with a new life as they are being digitized in the form of youtube videos and blogs. Performers are performing not just on the streets and festivals but online as well.

This dynamism in traditional arts and folklore performance which has been brought on fore with the emerging online resources should be welcomed as it has the potential to create respectable jobs for folk artists and preservation of their cultural heritage. The communities such Kalbeliyas from Rajasthan who are traditional snake charmers and dancers are now compelled to beg because their art is not getting as much public attention as it use to a couple of decades ago. A step must be taken to provide them a platform online where they can perform and earn their livelihood and live a respectful life. Despite being one of the UNESCO's cultural heritages, the Kalbeliya community is now marginalised both economically and culturally. 
Folklore, as it is passed on from generation to generation hence inheritable, can be seen as having an interrelationship with heritage and therefore, rightly as well as wisely termed by UNESCO as 'Cultural Heritage'. Since, folklore encourages the practice of passing-on to the next generations the oral knowledge of a community, it also enforces tradition. As discussed above, the folklore of a community can also be a source of paid entertainment wherein the performers get remunerated for their entertainment services and thus it can also represent a profession.

This paper tried to present the interrelationship between folklore, tradition, heritage and profession. This paper also tried to argue that the changing way of communications and online resources can generate a viable platform for folk artists to present their art and heritage to larger public and earn their livelihood to lead a respectful life. The only challenge, which the civil society, NGOs and the government can collectively address, is to provide a platform to the folk artists who are still not able to tap the potential which the internet offers.

These women sing various kinds of folk songs while doing back-breaking labor for their families like bringing fodder and grass for cattle, fetching wood and water from long distances etc. The women sing songs which is a part of their 'Folklore' and these songs are handed down from generation to generation and hence it is also a part of their 'Tradition'. With the growing commercialization of tradition, these women who used to sing for their own reasons in the past are now singing as professionals (with the help of NGOs) and they are earning their livelihoods out of this traditional practice, Singing has now become their 'Profession'. Since these songs are intangible and can not be recorded like objects in a museum, they are preserved and promoted with the singers themselves and that's why the UN has given it the status of an "Intangible Cultural Heritage" 
We can see that Folklore of a community can simultaneously reflect its Tradition, Profession as well as Heritage. In fact, they all can overlap and at times represent one another. They all are inextricably linked to each other and can carry the history, psychology, values and symbolic meanings of a community. In the case of Garhwal Himalayan women, their folklore (singing songs) is a part of their tradition which is being followed by several generations. Now, their folklore (singing songs) is their profession as well and cultural heritage for the whole world.

\section{References}

Sandis, Constantine. "Culture, Heritage, and Ethics." Cultural Heritage Ethics: Between Theory and Practice, edited by Constantine Sandis, 1st ed., Open Book Publishers, Cambridge, UK, 2014, pp. 11-20. JSTOR, www.jstor.org/stable/j.ctt1287k16.7.

Hughes, Everett C. "Professions." Daedalus, vol. 92, no. 4, 1963, pp. 655-668. JSTOR, www.jstor.org/stable/20026805.

Yadgar, Yaacov. "Tradition." Human Studies, vol. 36, no. 4, 2013, pp. 451-470. JSTOR, www.jstor.org/stable/24021628.

Bronner, Simon J., editor. Meaning of Folklore: The Analytical Essays of Alan Dundes. University Press of Colorado, 2007. JSTOR, www.jstor.org/stable/j.ctt4cgrzn.

Capila, Anjali. Images of Women in the Folk Songs of Garhwal Himalayas: a Participatory Research. Concept Pub. Co., 2002. 